УДК 374:159(001)

DOI: https://doi.org/10.54662/veresen.2.2021.04

\author{
Тетяна Тихонова, \\ ORCID iD 0000-0002-5276-3478 \\ доктор педагогічних наук, дочент, \\ завідувач кафедри педагогіки, \\ психології та менеджменту освіти \\ Миколаӥвський обласний інститут \\ післядипломної педагогічної освіти \\ вул. Адміральська, 4-а, 54001, Миколаїв, Україна \\ tetiana.tykhonova@moippo.mk.ua
}

\title{
МОДЕЛЬ ПСИХОЛОГО-АНДРАГОГІЧНОГО СУПРОВОДУ ПРОФЕСІЙНОГО САМОРОЗВИТКУ ПЕДАГОГА В УМОВАХ ПІСЛЯДИПЛОМНОЇ ОСВІТИ
}

Необхідність спрямування післядипломної освіти на професійний саморозвиток педагога потребує розроблення та впровадження моделі його супроводу, побудованого на психолого-андрагогічних засадах та інтерактивних технологіях, щуо сприяють постійному самовдосконаленню вчителів. Представлена у статті теоретична модель описує психолого-андрагогічний супровід професійного саморозвитку педагога в умовах післядипломної освіти через такі складові: мету - створення сприятливих умов щзодо професійної самоактуалізації та самореалізації педагогів; конщептуальні засади - підходи і принциии реалізащії супроводу; завдання, щзо спрямовані на створення умов щзодо саморозвитку професійних компетентностей; андрагогічні умови як способи підвищення ефективності супроводу; засоби супроводу, які реалізуються через інтерактивні технології навчання; критерії ефективності супроводу та його загальний результат.

Ключові слова: критерії ефективності психолого-андрагогічного супроводу; модель психолого-андрагогічного супроводу; післядипломна освіта; професійна діяльність педагога; професійний саморозвиток педагога; психолого-андрагогічний супровід; самоактуалізація; самовдосконалення.

(C) Тихонова Т. В., 2021

Вступ. Реалізація Концепції «Нова українська школа» потребує педагога, що має професійну та особистісну мобільність, володіє проєктувальними та конструювальними дидактичними вміннями, може виконувати в освітньому процесі ролі коуча, фасилітатора й тьютора, уміє професійно самовдосконалюватися, швидко реагуючи на суспільні та освітні перетворення. Таке соціальне замовлення актуалізує діяльність закладів післядипломної педагогічної освіти щодо сприяння неперервному професійному самовдосконаленню та саморозвиткові вчителів.

Процеси модернізації системи піс- лядипломної педагогічної освіти актуалізовано в національній законодавчо-нормативній базі: законах України «Про освіту» (2017 р.), «Про вищу освіту» (2014р.), «Про повну загальну середню освіту» (2020 р.), «Про професійний розвиток працівників» (2012р.), Концепції «Нова українська школа» (2016 р.), Концепції розвитку педагогічної освіти (2018р.), Професійному стандарті вчителя (2020р.), Положенні про сертифікацію педагогічних працівників (2018р.), Постанові КМУ про підвищення кваліфікації педагогічних та науково-педагогічних працівників (2019р.) та інших нормативно-правових документах, 
що спрямовують післядипломну освіту на підтримку суб'єктності сучасного вчителя.

Динамічне реформування освіти, поява нових суттєвих викликів щодо особистісно-професійних якостей освітян потребує посилення та модернізації змісту, методів і форм науково-методичного супроводу педагогів у системі післядипломної освіти, його психологічного й андрагогічного спрямування.

Актуальність визначеної проблеми посилюється також низкою суперечностей між:

- швидкими змінами в суспільстві, пов'язаними 3 глобалізацією світових процесів, пандемією, кризовими ситуаціями, та інертністю й консервативністю системи освіти;

- потребою інноваційних змін у системі освіти, пов'язаних із реалізацією Концепції «Нова українська школа» і недостатньою готовністю керівних і педагогічних кадрів до постійного професійного зростання та саморозвитку;

- необхідністю постійного професійного саморозвитку педагога в умовах реформування освіти та нерозробленістю науково обгрунтованої системи супроводу професійного саморозвитку педагога в системі післядипломної освіти.

Вирішення цих суперечностей можливе на основі здійснення психолого-андрагогічного супроводу педагога, що сприятиме його професійному розвиткові та самореалізації в мінливих умовах реформування сучасної освіти, допомагатиме вчителю у професійній самодетермінації та самоактуалізації професійного зростання на будь-якому етапі професійної діяльності.

Аналіз основних досліджень і публікацій. Професійний розвиток та саморозвиток особистості $€$ актуальним напрямом сучасної психології та досліджувався такими психологами, як К. Абульханова-Славська (Абульханова-Славська К., 1991), Г. Балл (Балл Г., 1994), Р. Бернс (Бернс Р., 1986), Ю. Кулюткін (Кулюткін Ю., 1986), А. Маслоу (Маслоу А., 1982), К. Роджерс (Роджерс К., 1994), С. Рубінштейн (Рубін- штейн С., 1973), К. Чарнецкі (Чарнецкі К., 1999) та ін. Окремі питання професійного розвитку також розглядались у працях дослідників у галузі педагогіки. Проблеми формування професійно-педагогічної та психологічної культури педагога порушувалися в роботах Ш. Амонашвілі (Амонашвілі Ш., 1995), В. Кан-Калика (Кан-Калик В., 1990), Н. Кузьміної (Кузьміна Н., 1985), О. Рудницької (Рудницька О., 1996), Р. Шакурова (Шакуров Р., 1985). Становлення і розвиток професіоналізму педагога вивчали I. Зязюн (Зязюн I., 2000), Л. Митина (Митина Л., 1998), І. Підласий (Підласий І., 1996), В. Сластьонін (Сластьонін В., 2005). Процес формування особистості педагога висвітлювали В. Орлов (Орлов В., 2000), Л. Рувинський (Рувинський Л., 1984), В. Семиченко (Семиченко В., 1992), В. Якунін (Якунін В., 1998). Складнощі самоактуалізації та самореалізації майбутнього вчителя в умовах професійно-педагогічної підготовки аналізували В. Моляко (Моляко В., 1989), О. Пєхота (Пехота О., 1997), С. Сисоєва (Сисоєва С., 1998), Т. Тихонова (ТихоноваТ. , 2001).

Значущість теми суб'єктності та професійного саморозвитку особистості зростає у зв'язку з актуалізацією андрагогічних досліджень, які доводять, що провідною діяльністю професійного розвитку особистості є саморегуляційна діяльність. На це у своїх дослідженнях вказують О. Антонова (Антонова О., 2018), С. Вітвицька (Вітвицька С., 2018), О. Дубасенюк (Дубасенюк О., 2018), Л. Лук'янова (Лук'янова Л., 2016), Е. Остапенко (Остапенко Е., 2015), В. Плющ (Плющ В., 2020). У цих умовах набуває значення якість психолого-андрагогічного супроводу підвищення кваліфікації педагога, який має бути спрямований саме на його професійний саморозвиток.

Метою статті є обгрунтування теоретичної моделі психолого-андрагогічного супроводу професійного саморозвитку вчителя в умовах післядипломної освіти. У рамках статті окреслено завдання: 1) визначити сутність понять «професійний саморозвиток педагога», «психолого-ан- 
драгогічний супровід професійного саморозвитку педагога»; 2) описати теоретичну модель психолого-андрагогічного супроводу професійного саморозвитку педагога в умовах навчання на курсах підвищення кваліфікації в Миколаївському інституті післядипломної педагогічної освіти (МОІППО); 3 ) охарактеризувати критерії й показники якості психолого-андрагогічного супроводу професійного саморозвитку педагога.

Виклад основного матеріалу. Поняття «професійний саморозвиток» досліджувалося багатьма психологами (Л. Виготський, О. Леонтьєв, С. Рубінштейн, А. Маслоу, К. Роджерс та ін.) та педагогами (І. Зязюн, О. Пєхота, В. Сластьонін, Г. Селевко та ін.). Теоретичне дослідження підходів до визначення поняття «професійний саморозвиток» провела Е. Остапенко (Остапенко Е., 2010). Вона пропонує такі класифікації підходів до визначення терміна «саморозвиток»: 1) за ключовим сегментом; 2) за формами саморозвитку; 3) за ракурсом дослідження феномена; 4) за підходами до розгляду феномена. За ключовим сегментом саморозвиток розглядається як: саморух, процес, механізм, зміна, технологія, потреба, здатність і характеристика, діяльність і внутрішня активність, або як процес і здатність. За формами саморозвитку поняття «саморозвиток особистості» наявний у єдності неусвідомлених та усвідомлених форм. За ракурсом дослідження феномена увага концентрується на професійних аспектах саморозвитку. За підходами до розгляду феномена виділяється два основних підходи до розуміння поняття «саморозвиток»: психологічний і процесуально організаційний (Остапенко Е., 2010, c. 50$)$.

У рамках нашого дослідження ми визначаємо професійний саморозвиток педагога як усвідомлене цілеспрямоване самопізнання, самопроєктування та самовдосконалення з метою досягнення високих результатів у професійній діяльності. Уважаємо, що процес професійного саморозвитку педагога $є$ видом його професійної діяльності і може характеризуватися через структуру педагогічної діяльності, модель якої описана професором В. Семиченко (Семиченко В., 1992). Ця модель містить такі структурні елементи: цілі, мотиви, суб' Єкти, об'єкти, зразки, умови, засоби, результати та корекція. Відповідно до поданої моделі процес професійного розвитку педагога можна описати так (адаптовано 3 нашої роботи (Тихонова Т., 2001)).

Професійний саморозвиток як діяльність $є$ формою здійснення активності суб'єкта цієї діяльності. Ця активність спрямована на змінення певних об'єктів. У разі професійного саморозвитку об'єктом є сам суб'єкт, його професійно-особистісні якості, знання та вміння.

Джерелом активності суб'єкта є мотиви, які актуалізуються на основі значущих для нього потреб. У разі стихійного саморозвитку мотивами можуть бути просування кар'єрними сходами, підвищення заробітної платні, зростання власного авторитету. Відповідно до мотивів формуються цุiлi: підвищити рівень кваліфікації, посісти певну посаду. Якщо цей процес протікає усвідомлено для педагога, його мотиви та цілі інші. Провідним є мотив особистісно-професійного самовдосконалення, самоактуалізації та самовираження у професійній діяльності. Згідно 3 цим основною метою педагога $є$ прагнення вдосконалити себе як професійну особистість, знати власні особистісно-професійні якості, уміти рефлексувати та регулювати свою професійну діяльність.

Конкретизація цілей, наповнення їх змістом відбувається через порівняння 3 окремими зразками чи створення власних зразків (того, що має бути досягнуте), інакше кажучи, моделей того результату, який відповідає меті. Зовнішніми зразками в цьому разі є професійний стандарт учителя, його компетентнісна (акмеологічна) модель, що прописані у відповідних нормативах. Внутрішнім зразком для педагога може бути його власна ідеальна модель, якої він прагне.

Діяльність завжди здійснюється на 
зовнішньому та внутрішньому тлі, яке створює умови для її протікання. Умови прямо чи опосередковано впливають на процес цієї діяльності. Професійний саморозвиток педагога здійснюється упродовж його професійної діяльності, тому зовнішніми умовами названого процесу $є$ зміни, які відбуваються в системі освіти, нові вимоги до компетентностей педагога, поява нових методик навчання, курси підвищення кваліфікації. Основною внутрішньою умовою професійного саморозвитку є усвідомлення педагогом суперечності між «Я реальним» та «Я як ідеальний учитель». Чим більш усвідомленим є для нього зміст цієї суперечності, тим ефективніше здійснюється професійний саморозвиток. Змінити внутрішні умови процесу професійного саморозвитку педагога ми не можемо, але через зміни зовнішніх умов (підвищення якості психолого-андрагогічного супроводу підвищення кваліфікації педагогів) можна впливати на змінення спрямованості педагога, його професійно-особистісних якостей, системи його ставлення до себе як до професіонала, а також до професійної діяльності.

Професійний саморозвиток педагога здійснюється необхідними та достатніми для цього засобами. Засобами реалізації зовнішніх умов названого процесу $є$ організоване підвищення кваліфікації педагога, його неперервна неформальна та інформальна освіта. Засобом реалізації внутрішніх умов професійного саморозвитку $\epsilon$ саморегуляційна діяльність педагога. Сaморегуляційна діяльність, якщо іiі розглядати в контексті професійної діяльності, $є$ інтеріоризованою діяльністю, що здійснюється паралельно з предметною діяльністю i спрямована на професійне самовдосконалення (Тихонова Т., 2001). Педагог повинен уміти регулювати свою діяльність у системах різних відносин: «Я - предметна діяльність» (діяльнісний аспект), «Я - інша людина» (особистісний аспект), «Я - Я» (суб'єктний аспект).

Саморегуляційна діяльність педагога містить у собі такі елементи: постановка цілей (самоактуалізація) - планування (самоорганізація) - відбір засобів та методів (самодетермінація) - реалізація задуманого (самореалізація) - аналіз результатів діяльності (самоаналіз і самооцінка). Уміння саморегуляційної діяльності є підгрунтям професійного саморозвитку, тому в процесі післядипломної освіти педагогів потрібно актуалізовувати вміння такої діяльності.

Результатом професійного саморозвитку педагога $\epsilon$ послідовність рівнів, що досягає педагог на шляху до свого професійного «акме»: від професійної компетентності до професійної культури і від них до професійної майстерності.

Критеріями професійного саморозвитку педагога можна вважати (Сластьонін В., 2005, с. 4):

- самоорганізацію якісних змін в особистості і в діяльності;

- домінування в структурі педагогічної діяльності дій педагога, спрямованих на професійне самооновлення, змінення власних способів діяльності;

- постановка та розв'язання щодо себе та своєї діяльності педагогічних, психологічних, організаційних, предметних задач;

- здатність учителя сприймати різні прояви професійного середовища як передумови власного професійного саморозвитку.

Сучасні вимоги до постійного професійного самовдосконалення педагога потребують й підвищення якості його психолого-андрагогічного супроводу в умовах післядипломної освіти. Значущість супроводу професійного розвитку та саморозвитку педагогів підкреслюють у своїх роботах такі науковці, як Ю. Вдовиченко (Вдовиченко Ю., 2016), І. Ніколаєску (Нiколаєску I., 2016), Г. Пономаренко (Пономаренко Г., 2013), В. Сидоренко (Сидоренко В., 2016) та ін.

Характеризуючи психологічний супровід майбутніх фахівців Г. Пономаренко визначає його як систему заходів, спрямованих на створення умов для успішного навчання, діяльності та розвитку студентів 
(Пономаренко Г., 2013, с. 94). І. Ніколаєску, досліджуючи науково-методичний супровід професійно-педагогічної самореалізації викладача, описує його як цілісну, системно організовану діяльність, у процесі якої створюються сприятливі умови для наукового й методичного зростання викладачів (Ніколаєску I., 2016, с. 36). Ю. Вдовиченко описує андрагогічний супровід педагога в процесі підвищення його кваліфікації як умову розвитку суб'єктної позиції, розглядає його як недирективну форму допомоги, спрямованої на сприяння самовизначенню і самореалізації педагога в освітньому середовищі (Вдовиченко Ю., 2016, с. 557). В. Сидоренко, обгрунтовуючи інноваційні підходи до професійного розвитку педагогів у системі післядипломної освіти, використовує поняття «науково-методичний супровід» та визначає його як «педагогічну технологію, що полягає у створенні мережевого диференційованого акмеологічного освітнього простору, де відбувається професійна взаємодія рівноправних партнерів на принципах людиноцентризму, гуманізму, фасилітативності, індивідуалізації, відбувається неперервний професійний розвиток педагогічних працівників за індивідуальними освітніми траєкторіями» (Сидоренко В., 2016, с. 24).

Ми розглядаємо психолого-андрагогічний супровід професійного саморозвитку педагога в системі післядипломної освіти як системно організовану освітню діяльність, побудовану на андрагогічних принципах та спрямовану на особистісно-професійне зростання педагогів, здійснення їхньої професійно-педагогічної самореалізації.

Із метою дослідження ефективності психолого-андрагогічного супроводу професійного саморозвитку педагогів у системі післядипломної педагогічної освіти в рамках наукового дослідження кафедри педагогіки, психології та менеджменту освіти МОІППО розроблена теоретична модель цього процесу, яка містить такі компоненти: мету, концептуальні засади, умови, завдання, засоби супроводу, критерії ефек- тивності та результати.

Метою психолого-андрагогічного супроводу професійного саморозвитку педагогів у системі післядипломної педагогічної освіти $є$ створення сприятливих умов щодо професійної самоактуалізації та самореалізації педагогів, їхнього особистісно-професійного зростання.

Концептуальними засадами психолого-андрагогічного супроводу професійного саморозвитку педагогів у системі післядипломної педагогічної освіти є підходи: системний, акмеологічний, особистісний, компетентнісний, технологічний та принциипи: системності, науковості, прогностичності, індивідуалізації, гнучкості, мобільності, рефлексивності, елективності, практичної спрямованості. Реалізація цих підходів і принципів у процесі підвищення кваліфікації педагогів дозволяє організувати освітню діяльність як процес дійсної фасилітації вчителя, розкриття його особистісно-професійного потенціалу.

Андрагогічними умовами, що сприяють професійному саморозвитку педагога в процесі підвищення кваліфікації, $є$ :

- урахування провідної ролі вчителя як суб'єкта підвищення кваліфікації, його професійних інтересів, особистісно-професійних якостей, спрямованостей, професійного досвіду тощо;

- функціонування освітнього середовища, спрямованого на практичне відпрацювання педагогічних інновацій, контекстність навчання, варіативність методів і форм навчання;

- фасилітація вчителів у процесі неформальної та інформальної освіти;

- застосування інтерактивних технологій навчання, основою яких $є$ активна суб'єктна та рефлексивна діяльність дорослої людини.

Завдання психолого-педагогічного супроводу професійного саморозвитку педагога в рамках розробленої моделі пов'язане 3 тематикою та змістом, який закріплено за кафедрою педагогіки, психології та менеджменту освіти Миколаївського ОІППО, і спрямоване на створення психо- 
лого-андрагогічних умов щодо професійного саморозвитку:

- соціальної, громадянської, лідерської та підприємницької компетентності;

- психологічної та емоційно-етичної компетентності;

- інформаційно-цифрової компетентності;

- компетентності педагогічного партнерства;

- інноваційної та рефлексивної компетентності;

- управлінських компетенцій керівників закладів освіти.

Засобами психолого-андрагогічного супроводу професійного саморозвитку педагога в системі післядипломної освіти мають бути інтерактивні технології навчання. Доцільність інтерактивних технологій у навчанні дорослих обгрунтовує в своїй роботі М. Скрипник, стверджуючи таке: «дорослий, як суб'єкт післядипломного навчання, має, по-перше, особливі психофізичні характеристики (зокрема гетерохронність, нерівномірність розвитку психічних функцій особистості дорослого упродовж усього життя; мінливість станів, тобто періоди кризи й оновлення змінюються періодами сталості, стабільності; розвиток ціннісних орієнтацій, життєвих планів і позицій; соціальну відповідальність); по-друге, психо- логічні бар'єри як механізми захисту в несприятливих ситуаціях; по-третє, мудрість як якісно нову форму інтелекту, що визначається як експертні знання про фундаментальні закони і реалії життя; по-четверте, соціальну, моральну, духовну потребу в спілкуванні й передачі набутого досвіду» (Скрипник М., 2013, с. 20). Вона пропонує, проєктуючи інтерактивні технології навчання, керуватися «принципами розвитку знань про закономірності формування креативності особистості фахівця в процесі інтеракції (діалогічності; варіативності, відкритості; гуманітаризації; проблемності; різноманітності)» (Скрипник М., 2013, c. 21).

Розроблена модель передбачає використання таких інтерактивних технологій, що сприяють професійному саморозвитку педагога: особистісно-професійна само- та взаємодіагностика, воркшопи, майстеркласи, тренінги, дискусії, кейс-методи, контекстне навчання, ділові ігри, інтерактивні вправи, дослідницькі технології тощо.

У процесі дослідницької роботи визначено критерії та показники ефективності психолого-андрагогічного супроводу професійного саморозвитку педагога (табл. 1) та розроблено засоби опитування слухачів курсів підвищення кваліфікації щодо оцінювання супроводу, який здійснюють

Таблиия 1.

\section{Критерії та показники ефективності психолого-андрагогічного супроводу про- фесійного саморозвитку педагога}

\begin{tabular}{|c|l|}
\hline Критерії & \multicolumn{1}{|c|}{ Показники } \\
\hline \multirow{2}{*}{ Цілеспрямованість } & Спрямованість на професійннй саморозвиток учителя \\
\cline { 2 - 2 } & Відповідність андрагогічним принципам \\
\hline \multirow{3}{*}{ Актуальність } & Новизна \\
\cline { 2 - 2 } & Відповідність професійному стандарту вчителя \\
\cline { 2 - 2 } & Відповідність завданням реформування освіти \\
\hline \multirow{3}{*}{ Змістовність } & Науковість \\
\cline { 2 - 2 } & Повнота \\
\cline { 2 - 2 } & Цілісність \\
\hline \multirow{2}{*}{ Гнучкість } & Варіативність методів і форм \\
\cline { 2 - 2 } & Особистісна орієнтація \\
\hline \multirow{3}{*}{ Результативність } & Змотивованість учителя на професійний саморозвиток \\
\cline { 2 - 2 } & Володіння методами професійного саморозвитку \\
\cline { 2 - 2 } & Рефлексивні вміння \\
\hline
\end{tabular}

Джерело складено автором самостійно 
викладачі кафедри.

Загальним результатом психолого-андрагогічного супроводу професійного саморозвитку педагога $є$ сформованість його загальних умінь щодо створення й реалізації програми власного особистісно-професійного самовдосконалення.

Висновки. В умовах фундаментальних змін, що відбуваються в системі вітчизняної освіти, зростання ролі вчителя як провідника нових педагогічних ідей, післядипломна педагогічна освіта має бути спрямована на постійний професійний саморозвиток педагога, який ми визначаємо як усвідомлене цілеспрямоване самопізнання, самопроєктування та самовдосконалення 3 метою досягнення високих результатів у професійній діяльності.

Спрямування післядипломної освіти на професійний саморозвиток педагога потребує розроблення та впровадження моделі психолого-андрагогічного супроводу післядипломного навчання, побудованого на андрагогічних засадах та інтерактив- них технологіях, що сприяють постійному самовдосконаленню вчителів. Розроблена нами теоретична модель психолого-андрагогічного супроводу професійного саморозвитку педагога в умовах післядипломної освіти містить такі складові: мету - створення сприятливих умов щодо професійної самоактуалізації та самореалізації педагогів; конщептуальні засади - підходи і принципи реалізації супроводу; завдання, що спрямовані на створення умов щодо саморозвитку професійних компетентностей; андрагогічні умови як способи підвищення ефективності супроводу; засоби супроводу, які реалізуються через інтерактивні технології навчання; критерії ефективності супроводу та його загальний результат.

Перспективи дослідження. Подальше дослідження ефективності психолого-андрагогічного супроводу професійного саморозвитку педагога передбачає впровадження його моделі в освітній процес МОІППО та ï оцінювання й відповідного коригування.

\section{ЛІТЕРАТУРА}

1. Андрагогічний супровід при підвищенні кваліфікації педагогів / Ю. П. Вдовиченко, Р. С. Коритнюк, Л. Л. Давтян, О. Я. Роздорожнюк, А. О. Дроздова // Збірник наукових праць співробітників НМАПО ім. П. Л. Шупика. - 2016. - Вип. 26. - С. 555-562. - Режим доступу: http://nbuv.gov.ua/UJRN/Znpsnmapo_2016_26_94

2. Лук'янова Л. Б. Підготовка педагогічного персоналу для роботи 3 дорослими: теоретичний і методичний аспекти / Л. Б. Лук’янова. - К. : ІПООД НАПН України, 2016. -265 c.

3. Ніколаєску I. О. Науково-методичний супровід професійно-педагогічної самореалізації викладача системи післядипломної освіти засобами інформаційно-комунікаційних технологій / I. О. Ніколаєску // Електронне наукове фахове видання «Народна освіта». - 2016. - Вип. № 3 (30). - С. 35-41.

4. Остапенко Е. О. Дослідження підходів до визначення поняття «саморозвиток» / Е. О. Остапенко // Наукові праці [Чорноморського державного університету імені Петра Могили комплексу «Києво-Могилянська академія»]. Сер. : Педагогіка. - 2010. - Т. 136, Вип. 123. - С. 49-53. - Режим доступу: http://nbuv.gov.ua/UJRN/ Npchduped_2010_136_123_10

5. Пехота Е. Н. Индивидуализация профессионально-педагогической подготовки учителя / Е. Н. Пехота. - Киев : Вища школа, 1997. - 281 с.

6. Плющ В. М. Модель формування готовності майбутніх учителів природничих дисциплін до професійного самовдосконалення / В. М. Плющ // Наукові записки. Серія : Педагогічні науки. - 2020. - Вип. 185 (Грудень). - С. 147-52.- Режим доступу: DOI:https:// doi.org/10.36550/2415-7988-2019-1-185-147-152 
7. Пономаренко Г. О. Психолого-педагогічний супровід професійного розвитку студентів вищих навчальних закладів / Г. О. Пономаренко // Педагогічний альманах. - 2013. - Вип. 20. - С.91-96. - Режим доступу: http://nbuv.gov.ua/UJRN/pedalm_2013_20_17

8. Семиченко В. А. Концепция целостности и её реализация в профессиональной подготовке будущих учителей (психолого-педагогический аспект). Автореф. дис. ... д-ра психол. наук: 19.00.07 / В. А. Семиченко / Институт проф. образования АПН Украины. К., 1992. - 48 с.

9. Сидоренко В. В. Інноваційні напрями науково-методичного супроводу професійного розвитку педагогічних працівників у системі післядипломної освіти / В. В. Сидоренко // Інформаційний збірник для директора школи та завідуючого дитячим садком. - К. : РА «Освіта України». - 2016. - № 7-8 (48). - С. 22-29.

10. Скрипник М. І. Інтерактивні технології в післядипломному навчанні : довідник / М. І. Скрипник. - К. : НАПН України; ДВНЗ «УН-Т менедж. освіти», 2013. - 202 с.

11. Сластенин В. А. Профессиональное саморазвитие учителя / Виталий Александрович Сластенин // Сибирский педагогический журнал. - 2005. - № 2. - С. 3-12. - Режим доступу: https://cyberleninka.ru/article/n/professionalnoe-samorazvitie-uchitelya

12. Слободенюк Л. І. Психологічний супровід профільного навчання / за ред. Л. І. Слободенюк. - Херсон : РІПО, 2010. - 147 с.

13. Тихонова Т. В. Педагогічні умови професійного саморозвитку майбутнього вчителя інформатики. Дис. ... канд. пед. наук: 13.00.04 / Т. В. Тихонова / Інститут педагогіки АПН України.- К., 2001. - 196 с.

\title{
МОДЕЛЬ ПСИХОЛОГО-АНДРАГОГИЧЕСКОГО СОПРОВОЖДЕНИЯ ПРОФЕССИОНАЛЬНОГО САМОРАЗВИТИЯ ПЕДАГОГОВ В УСЛОВИЯХ ПОСЛЕДИПЛОМНОГО ОБРАЗОВАНИЯ
}

\author{
Тихонова Татьяна, \\ доктор педагогических наук, дочент, \\ заведуюшая кафедрой педагогики, \\ психологии и менеджмента образования \\ Николаевский областной институт \\ последипломного педагогического образования \\ ул. Адмиральская, 4-а, 54001, г. Николаев, Украина \\ tetiana.tykhonova@moippo.mk.ua
}

Необходимость иеленаправленности последипломного образования на профессиональное саморазвитие педагога требует разработки и внедрения такой модели его сопровождения, которая основана на психолого-андрагогическом подходе и интерактивных технологиях, способствующих постоянному самосовершенствованию учителей. Представленная в статье теоретическая модель описывает психолого-андрагогическое сопровождение профессионального саморазвития педагога в условиях последипломного образования с помощьью следующих составляющих: иель - создание благоприятных условий для профессиональной самоактуализаџии и самореализации педагогов; концептуальные основы - подходы и принципы реализации сопровождения; задания, направленные на создание условий для саморазвития профессиональных компетентностей; андрагогические условия как способы повышения эффективности сопровождения; средства сопровождения, которые реализуются через интерактивные технологии обучения; критерии эффективности сопровождения и его результат.

Ключевые слова: критерии эффективности психолого-андрагогического сопро- 
вождения; модель психолого-андрагогического сопровождения; последипломное образование; профессиональная деятельность педагога; профессиональное саморазвитие педагога; психолого-андрагогическое сопровождение; самоактуализация; самосовершенствование.

\title{
PSYCHOLOGICAL AND ANDRAGOGICAL SUPPORT MODEL OF TEACHER SELF-DEVELOPMENT IN POSTGRADUATE EDUCATION
}

\author{
Tykhonova Tetiana, \\ Doctor of Pedagogic Sciences, Head of the Department \\ of pedagogy, psychology and education management \\ Mykolaiv In-Service Teachers Training Institute \\ 4-a Admiralska Street, 54001, Mykolaiv, Ukraine \\ tetiana.tykhonova@moippo.mk.ua
}

The article defines the concept - "professional self-development of a teacher», "psychological and andragogical support of professional self-development of a teacher»; the author describes the theoretical psychological and andragogical support model of of the teacher professional self - development in the conditions of training on advanced training courses in the Nikolaev institute of postgraduate pedagogical education, characterizes criteria and indicators of quality of psychological and andragogical support of professional selfdevelopment of the teacher.

The professional self-development of a teacher is defined by the author as a conscious purposeful self-knowledge, self-design and self-improvement in order to achieve high results in professional activities.

The need to direct postgraduate education to the professional self-development of teachers requires the development and implementation of a model of its support, based on psychological and andragogical principles and interactive technologies that promote continuous self-improvement of teachers. Psychological and andragogical support of professional selfdevelopment of a teacher in the system of postgraduate education is defined as a systematically organized educational activity, built on andragogical principles and aimed at personal and professional growth of teachers.

The theoretical model presented in the article describes the psychological and andragogical support of professional self-development of a teacher in postgraduate education through the following components: the purpose - to create favorable conditions for professional self-actualization and self-realization of teachers; conceptual principles - approaches and principles of support implementation; tasks aimed at creating conditions for self-development of professional competencies; andragogical conditions as ways to increase the effectiveness of support; support tools that are implemented through interactive learning technologies; criteria for the effectiveness of support and its overall result.

Further research of efficiency of psychological and andragogical support of professional self-development of the teacher provides introduction of its model in educational process and its estimation and corresponding adjustment.

Keywords: criteria for the effectiveness of psychological and andragogical support; model of psychological and andragogical support; postgraduate education; professional activity of a teacher; professional self-development of a teacher; psychological and andragogical support; self-actualization; self improvement. 


\section{REFERENCES}

1. Lukianova, L. B. (2016). Pidhotovka pedahohichnoho personalu dlia roboty $z$ doroslymy: teoretychnyi i metodychnyi aspekty [Training of teaching staff to work with adults: theoretical and methodological aspects]. K.: IPOOD NAPN Ukrainy (ukr).

2. Nikolaiesku, I. O. (2016). Naukovo-metodychnyi suprovid profesiino-pedahohichnoi samorealizatsii vykladacha systemy pisliadyplomnoi osvity zasobamy informatsiinokomunikatsiinykh tekhnolohii [Scientific and methodical support of professional and pedagogical self-realization of the teacher of the system of postgraduate education by means of information and communication technologies]. Elektronne naukove fakhove vydannia «Narodna osvita», 3(30), 35-41 (ukr).

3. Ostapenko, E. O. (2010). Doslidzhennia pidkhodiv do vyznachennia poniattia «samorozvytok» [Research of approaches to the definition of «self-development»]. Naukovi pratsi Chornomorskoho derzhavnoho universytetu imeni Petra Mohyly kompleksu "KyievoMohylianska akademiia». Ser.: Pedahohika, (vol 136), 123, 49-53. Retrieved from: http:// nbuv.gov.ua/UJRN/Npchduped_2010_136_123_10 (ukr).

4. Pehota, E. N. (1997). Individualizacija professional'no-pedagogicheskoj podgotovki uchitelja [Individualization of professional and pedagogical training of teachers]. Kiev: Vishha shkola (rus).

5. Pliushch, V. M. (2020). Model formuvannia hotovnosti maibutnikh uchyteliv pryrodnychykh dystsyplin do profesiinoho samovdoskonalennia [Model of formation of readiness of future teachers of natural sciences for professional self-improvement]. Naukovi zapysky. Seriia: Pedahohichni nauky, 185, 147-52. DOI:https://doi.org/ 10.36550/2415-79882019-1-185-147-152 (ukr).

6. Ponomarenko, H. O. (2013). Psykholoho-pedahohichnyi suprovid profesiinoho rozvytku studentiv vyshchykh navchalnykh zakladiv [Psychological and pedagogical support of professional development of students of higher educational institutions]. Pedahohichnyi almanakh, 20, 91-96. Retrieved from: http://nbuv.gov.ua/UJRN/pedalm_2013_20_17 (ukr).

7. Semichenko, V. A. (1992). Koncepcija celostnosti i ejo realizacija v professional'noj podgotovke budushhih uchitelej (psihologo-pedagogicheskij aspekt) [The concept of integrity and its implementation in the professional training of future teachers (psychological and pedagogical aspect)]. (Extended abstract of doctor's thesis). Kiev: Institut prof. obrazovanija APN Ukrainy (rus).

8. Skrypnyk, M. I. (2013). Interaktyvni tekhnolohii v pisliadyplomnomu navchanni: dovidnyk [Interactive technologies in postgraduate study: a handbook]. K.: NAPN Ukrainy; DVNZ «Un-t menedzh. osvity» (ukr).

9. Slastenin, V. A. (2005). Professional'noe samorazvitie uchitelja [Professional selfdevelopment of a teacher]. Sibirskij pedagogicheskij zhurnal, 2, 3-12. Retrieved from: https:// cyberleninka.ru/article/n/professionalnoe-samorazvitie-uchitelya (rus).

10. Slobodeniuk, L. I. (2010). Psykholohichnyi suprovid profilnoho navchannia [Psychological support of specialized training]. Kherson: RIPO (ukr).

11. Sydorenko, V. V. (2016). Innovatsiini napriamy naukovo-metodychnoho suprovodu profesiinoho rozvytku pedahohichnykh pratsivnykiv u systemi pisliadyplomnoi osvity [Innovation in the direct scientific-methodical super-guide of professional development of pedagogical pratsivniki in the system of graduate education]. Informatsiinyi zbirnyk dlia dyrektora shkoly ta zaviduiuchoho dytiachym sadkom, 7-8 (48), 22-29 K.: RA «Osvita Ukrainy» (ukr).

12. Tykhonova, T. V. (2001). Pedahohichni umovy profesiinoho samorozvytku maibutnoho 
vchytelia informatyky [Pedagogical conditions of professional self-development of the future teacher of computer science]. (Candidate's thesis). Kyiv: Instytut pedahohiky APN Ukrainy (ukr).

13. Vdovychenko, Yu. P., Korytniuk, R. S., Davtian, L. L., Rozdorozhniuk, O. Ya. \& Drozdova, A. O. (2016). Andrahohichnyi suprovid pry pidvyshchenni kvalifikatsii pedahohiv [Andragogical support in professional development of teachers]. Zbirnyk naukovykh prats spivrobitnykiv NMAPO im. P. L. Shupyka, 26, 555-562. Retrieved from: http://nbuv.gov.ua/ UJRN/Znpsnmapo_2016_26_94 (ukr). 